\title{
Capelães na marinha mercante portuguesa: engajamento e perfis profissionais (séculos XVIII e XÌX)
}

por

Jaime Rodrigues ${ }^{1}$

EFLCH/UNIFESP

\begin{abstract}
Em meio às diversas profissões encontradas nas fontes referentes à marinha mercante lusa na época moderna, os capelães destacam-se como um oficio cuja formação se dava exclusivamente em terra, cabendo a eles o socorro espiritual dos tripulantes. A intenção aqui é definir suas funções e o perfil desses homens, bem como traçar breves biografias profissionais de capelães em circulação desde o porto de Lisboa até os domínios ultramarinos, sobretudo os da América portuguesa, entre meados do século XVIII e as primeiras décadas do século XIX, com recuos para temporalidades anteriores a fim de enfatizar a antiguidade da presença de sacerdotes católicos a bordo.
\end{abstract}

PAlaVRas-CHAVE: história maritima; navegação; perfis profissionais; capelão maritimo.

Cómo CITAR ESTE ARtículo / Citation: Rodrigues, Jaime, “Capelães na marinha mercante portuguesa: engajamento e perfis profissionais (séculos XVIII e XİX)", Revista de Indias, LXXIX/276 (Madrid, 2019): 399-431. https://doi.org/10.3989/revindias.2019.012.

\section{INTRODUÇÃO}

A forma mais óbvia, ainda que apropriada, da historiografia abordar a presença de capelães nas embarcações mercantes ou de guerra refere-se às práticas religiosas conduzidas por esses homens. Aqui, optei por uma abordagem diferente, que foca a questão da inserção profissional na qual eles também estiveram imersos.

1 rodriguesjaime@gmail.com, ORCID iD: https://orcid.org/0000-0002-9893-7365. 
Ainda conhecemos pouco as formas de recrutamento para o clero regular e o secular em Portugal nos tempos modernos. Algumas pistas são sugestivas do tipo de gente atraída para o sacerdócio e suas motivações:

Nos escalões mais baixos do clero secular, pior remunerados e menos exigentes do ponto de vista da formação intelectual, encontraríamos (...) aqueles cuja origem social estava nos grupos das famílias secundárias das vereações, dos pequenos proprietários e rendeiros e dos artesãos, gente que, em princípio, podia dispor de bens de raiz que assegurassem a constituição de um patrimônio. Na comarca trasmontana, em finais do Antigo Regime, a carreira sacerdotal surgia não tanto como uma 'fuga à miséria', mas mais como um investimento familiar no prestígio social: a 'gente rústica' buscava ordenar os filhos 'com o fim de honrarem as famílias ${ }^{2}$.

Diferentemente da historiografia espanhola, em Portugal e no Brasil as carreiras eclesiásticas tem merecido atenção menor por parte dos historiadores. Nuno Monteiro, Fernanda Olival e Aldair Rodrigues, entre outros, são exemplos de autores que tem abordado as carreiras eclesiásticas. Os dois primeiros observaram que "gente dos mais diversos estratos populares até a mais refinada aristocracia ingressava no clero por razões e com objetivos não coincidentes", indagando-se sobre as possibilidades de ascensão social, sobre o ingresso na carreira em função do mérito e as oportunidades oferecidas aos recrutados, entre outras questões ${ }^{3}$.

Algumas das exigências para o ingresso na carreira foram inscritas nas constituições sinodais. No século XVIII, ainda se exigiam dotes entre 15 e 16 mil réis (na Bahia, o valor chegava a 25 mil réis) dos ingressantes nas ordens religiosas, embora esses valores devam ter sido reajustados a fim de compensar a inflação. Havia restrições explícitas, como os defeitos mecânicos e de sangue, mas isso nem sempre era impeditivo do acesso à carreira eclesiástica, na medida em que cristãos novos e descendentes de trabalhadores braçais comumente conseguiam se ordenar. Se não era preciso ser nobre para tornar-se padre, a "qualidade" da família em que se nascia importava para os rumos profissionais. Patrocínios e influências distintas viabilizavam ou não a chegada aos escalões eclesiásticos intermediários e superiores, bem como para se conseguir uma mercê ou paróquia mais disputada. Tornar-se o pároco da igreja onde se fora batizado era comum em Portugal e outros lugares da Europa. Assim, predominava nas paróquias o clero recrutado localmente ${ }^{4}$.

2 Rodrigues, 2010: 109.

3 Olival e Monteiro, 2003: 1214.

4 Olival e Monteiro, 2003: 1221-1129. 
Os capelães embarcados escapavam a essa lógica, na medida em que nem todos conseguiam empregos nos locais onde haviam nascido, não dispunham de dotes em bens ou dinheiro que lhes permitissem ingressar em uma ordem ou não contavam com padrinhos capazes de alavancar suas carreiras. Premidos por condições sociais adversas, eles também podem ter optado pela vida menos estável no mar em razão de suas vontades. A compreensão da vida religiosa como carreira profissional e, sobretudo, do engajamento marítimo como opção, foi o mote desta pesquisa.

Observar o fenômeno do engajamento dos capelães só foi possível pela consulta aos registros seriais de matrículas dos tripulantes de navios mercantes, produzidos sistematicamente em Portugal desde 1767. A partir dos dados contidos nesses registros, pude perseguir os indivíduos em mais de uma viagem e buscar, em outros documentos, evidências que me permitissem elaborar biografias profissionais desses homens. $\mathrm{O}$ método pode ser estendido a outras funções de bordo, como os capitães, mestres e cirurgiões, por exemplo, embora a documentação sobre os marinheiros comuns, por outro lado, seja bem mais escassa.

\section{LEGISLAÇÃo E OBRIGAÇÕES}

Em meio ao extenso rol das profissões marítimas até o século XIX, a figura dos capelães possuía algumas especificidades que merecem ser tratadas aqui. Eles eram dos poucos profissionais formados em terra e não nas lidas marítimas, ainda que tivessem que se adequar aos elementos determinantes da natureza, aos ritmos e horários do trabalho a bordo. Diferentemente de outros tripulantes, os sacerdotes embarcados não tinham tarefas braçais e, mesmo sendo oficiais, não exerciam o comando.

Comecemos por uma definição: "sacerdote assalariado, que tem obrigação de dizer missa em oratório ou igreja (...)". Foi com essas palavras que Raphael Bluteau fixou o sentido do vocábulo capelão em princípios do século XVIII. Primeiramente, e esta é a definição que mais se aproxima do que pretendo discutir aqui, tratava-se de um assalariado. O dicionarista notou também a relação entre o cargo e a hierarquia social, ao indicar que o capelão detinha "título de cortesania, como quando dizem frades, ou clérigos"5. Ele era o segundo indivíduo a ser matriculado, sempre após o capitão, o que reforçava a noção de hierarquia e definia seu lugar entre os demais homens a bordo do

$5 \mathrm{O}$ autor apresentou ainda o significado de Capelão Mor, ligado à Capela Real lusitana, e as honrarias decorrentes desse cargo. Ver Bluteau, 1712: 122-123. 
ponto de vista da distinção social. As funções dos capelães estavam ligadas ao instituto do padroado, já que, na Armada, seus salários eram pagos pelo Estado português e, como funcionários eclesiásticos, eram tratados pela monarquia de modo similar ao dos funcionários civis 6 .

Os capelães sobre os quais este texto versa são aqueles engajados na marinha mercante portuguesa entre os séculos XVIII e XIX. Sua presença a bordo, embora não fosse remunerada com dinheiro do erário luso, era ditada por leis do Reino cujo objetivo declarado era prover os navegantes de conforto espiritual, tendo eles ainda o dever de ministrar os sacramentos às gentes em circulação pelos diferentes domínios coloniais.

$\mathrm{Na}$ legislação, percebe-se que os navios eram lugares privilegiados para o exercício da salvação de almas. As leis de arqueação do trafico negreiro, ao mesmo tempo em que definiam o número de escravos embarcados conforme as tonelagens dos navios, também insistiam na presença de sacerdotes a bor$\mathrm{do}^{7}$. É o que podemos ler, por exemplo, na lei de 18 de março de 1684 , obrigando todos os navios negreiros a "levar um sacerdote, que sirva de capelão, para neles dizer missa ao menos nos dias santos e assistir aos moribundos"8. A obrigação decerto não era plenamente cumprida, a julgar pelo número de vezes em que foi reiterada e ampliada para outros segmentos da marinha mercante e em partes específicas dos domínios, como a carta régia de 27 de março de 1688, destinada ao governador da capitania do Rio de Janeiro. Nela, reforçava-se a conveniência que os navios tivessem capelães. Todas as ordens antigas não eram o bastante, por isso foram emitidas novas, para que "nenhum navio dessa capitania saia sem trazer certidão do ouvidor geral (...) pela qual conste que chegou e volta com capelão", denotando, assim, uma preocupação em controlar as idas e vindas dos padres embarcados, obrigando-os a retornar sempre ao ponto de partida.

Nem sempre se encontrava sacerdote disposto a atravessar os mares no cumprimento das leis. Na Espanha, por exemplo, quando faltasse capelão no navio, uma ordem de 1582 mandava os marinheiros se confessarem e comungarem antes de embarcar e nas escalas ${ }^{10}$. Alterações legais mantiveram a figura do capelão ao longo do século XVIII, bem como suas funções de admi-

${ }^{6}$ Em poucas palavras, o padroado era a combinação de direitos, privilégios e deveres da Coroa portuguesa na África, Ásia e América, concedidos pelo Papado, no dizer de Boxer, 2002: 242-244; 1981: 98-9.

7 Rodrigues, 2005: 209. Lara, 2007.

8 Lara, 2000: 192.

9 Ibidem: 199-200.

10 Muñoz, 2004: 152-153. 
nistrador dos sacramentos cristãos às equipagens, em instruções de 1762. A partir daí e até 1783, os capelães submetiam-se ao vicário geral do Exército e da Armada, jurisdição separada da dos bispos ${ }^{11}$. Nada parecido regulava a atuação dos capelães na marinha mercante lusa.

$\mathrm{Na}$ América portuguesa também não se achava muitos sacerdotes dispostos às viagens marítimas. A falta deles nos navios negreiros que iam para Angola e na cabotagem entre as diferentes capitanias pesaria nas consciências do governador e do bispo locais, responsáveis finais pela negociação do pagamento dos capelães "porque muitas vezes estes se não acomodam com os mestres sobre os salários que se lhes devem dar"12. Cabia aos administradores coloniais obrigar os mestres a embarcar os religiosos, e o bispo convenceria o capelão escolhido a aceitar o pagamento combinado.

No projeto não implementado de uma companhia de comércio da Costa da Mina em 1756, definia-se o papel e as características dos capelães nos navios do tráfico. Para obtê-los, os negreiros deveriam pagar salários maiores que a média. Se na América não era fácil encontrar capelão, consegui-los para os navios que partiam da África ou para trabalhar naquele continente era ainda mais difícil ${ }^{13}$.

A Coroa, os armadores e oficiais de navios, bem como as autoridades civis e eclesiásticas nas colônias, foram personagens de um embate duradouro, centrado no cumprimento das leis que obrigavam as embarcações a levarem sacerdotes, pagando-os pelos serviços prestados. Um dos níveis de conflito, que precedia o embarque, era justamente o valor a ser pago, opondo mestres e capelães. Se a questão não chegasse a bom termo provavelmente haveria tensões a bordo, sobretudo quando um capelão embarcava contra a vontade por não receber uma remuneração considerada justa.

As exigências legais relativas ao embarque de sacerdotes levantavam poderosa oposição dos comerciantes e das próprias autoridades eclesiásticas. Foi o caso, por exemplo, da exigência de que os navios vindos de Luanda para os portos da América portuguesa trouxessem entre suas tripulações "sacerdotes práticos nas línguas dos sertões [de Angola], para que assim melhor se acuda à salvação dos escravos que nelas se embarcam" ou que as carregações fossem provenientes de lugares cujas línguas os padres conhecessem. O Cabido da Sé de Angola, que recebera essa ordem em 1693, afirmava que a mesma não podia ser cumprida e sugeriu uma alternativa afinal aceita pelo Conselho Ultramarino: que se embarcassem capelães "filhos daquele Reino",

\footnotetext{
11 Fernández-Turégano, 2011: 194.

12 Lara, 2000: 200.

13 Verger, 1981: 47-48.
} 
seguramente pouquíssimos, ou que "sempre na tal embarcação v[e]nham alguns escravos ladinos, que s[i]rvam de intérpretes, de que muitas vezes se valiam, e o mesmo fazem os missionários capuchos por aquele sertão"14.

Mais de meio século depois, vamos reencontrar os legisladores empenhados em proibir a ida de embarcações do Brasil à África sem levar capelão na equipagem. Em correspondência vinda do Reino, o vice-rei Conde de Atouguia era avisado de que as providências sobre o assunto tinham sido tomadas pelo Conselho Ultramarino em 1697, a fim de limitar a ação de capitães que se recusavam a cumprir as ordens, sob pena de passarem um mês na prisão e pagarem multa de $400.000^{15}$. Em 1760, era a vez do vice-rei Antônio de Almeida Soares e Portugal receber a resposta à consulta feita por seu antecessor, Marcos de Noronha, sobre o fato de que "nos navios que faziam viagem para essa América morriam algumas pessoas sem confissão". Se leis desde o século XVII tentaram impedir esse prejuízo com contínuas restrições a navegar sem capelão, isso nem sempre se devia apenas à desobediência dos oficiais marítimos ou das vistas grossas das autoridades portuárias. $\mathrm{O}$ próprio juízo eclesiástico mostrou ao rei que nos navios pequenos "não há comodidade para poderem levantar altar para o sacrifício da missa" e por isso "teriam uma certidão do provisor do arcebispo [da Bahia], por onde os exime de levarem capelão". A situação vinha gerando abusos e "prejuízo à salvação de todos esses navegantes", não só pela falta da missa, mas também pela ausência de quem desse a extrema unção e ouvisse confissão, bem como o batismo dos negros que morriam a bordo. São evidentes as pressões sobre a Coroa que, neste caso, decidiu revogar a Provisão de 21 de junho de 1727 e ordenar que se executasse o Regimento das Arqueações e a Provisão de 27 de março de 1688, “de sorte que não vá nenhuma embarcação para a Costa de África sem levar capelão", mesmo que pequena ${ }^{16}$.

Focando na legislação, ao menos dois níveis de conflito são identificados. $\mathrm{O}$ primeiro refere-se ao pagamento, fonte de divergência entre contratante (em geral capitães e/ou mestres) e contratados. O segundo nível, não separado do primeiro, refere-se à condição em que o trabalho seria desenvolvido e à dificuldade em se encontrar sacerdotes católicos aptos ou dispostos a desempenhar a função de capelão marítimo. Adiante, veremos como essas questões aparecem nas fontes do período aqui recortado.

14 Lara, 2000: 453-454. Sobre o diminuto clero nativo da África Ocidental, aí incluída Angola, ver Boxer, 1981: 14-23.

15 Lara, 2000: 317-318, Provisão de 30 de outubro de 1752.

16 Lara, 2000: 341, Provisão de 29 de dezembro de 1760, reforçada pela Ordem de 19 de dezembro de 1764. 


\title{
FunÇÕES E CONFLITOS
}

$\mathrm{O}$ trabalho de um capelão de navio era árduo, a julgar pelos relatos dos tempos modernos, que consideravam os marinheiros como "os piores cumpridores dos mandamentos da Igreja (...)"17. Pago por empreitada, por viagem ou por mês, conforme a negociação, o capelão de navio era uma figura frequente e antiga nos navios mercantes europeus de diferentes confissões. Vamos encontrá-lo nos navios portugueses durante o fim dos tempos medievais e na Carreira da Índia ${ }^{18}$. De modo semelhante, nas embarcações espanholas, os sacerdotes tornam-se figuras constantes desde as viagens de Colombo à América ${ }^{19}$. Mesmo quando as viagens eram estritamente mercantes, as naus levavam capelães e, a partir da obrigatoriedade do embarque deles, os marinheiros talvez tenham se iniciado em uma espiritualidade que nem todos praticavam antes ${ }^{20}$.

No cotidiano dos navios, era dos padres embarcados a responsabilidade pelo combate aos males do espírito, em um lugar onde imperava a insegurança em meio aos elementos indomáveis da natureza: "não é de estranhar que nas viagens longas se administrassem sacramentos como a extrema unção, a confissão e a comunhão, enquanto nos momentos de bonança se celebravam missas e outros rituais que a presença de um prelado tornava mais solenes" 21 .

Lidando com os relatos de sacerdotes embarcados, Miceli observou ser rara a solidariedade nesse ambiente, marcado por profundas desigualdades. Mesmo que seu papel de salvador de almas em perigo iminente fosse reconhecido pelos demais, nem por isso o capelão era especialmente respeitado pelos marinheiros comuns em comparação com outros oficiais. O relato do padre Gaspar Barzaens em viagem de Lisboa a Goa na nau São Pedro, em 1548, é esclarecedor:

\begin{abstract}
... todos os irmãos se marearam, e assim foram alguns [dias] mareados e sem poder comer; nem tínhamos quem nos fizesse de comer no fogão, pelo que me foi necessário tomar a cruz às costas, e dispus-me logo [a] fazer de comer no fogão, de onde nenhuma cortesia me tinha às ordens; e quando escapei sem bofetadas, que os grumetes me queriam dar, e do fumo que havia, não fiz tão pouco. Neste ofício continuei alguns dias, e com tão pouco proveito, que nunca os irmãos podiam gostar [de] comer; porque umas vezes me furtaram a panela, outros ma quebraram, outros ma entornavam, de maneira que não podia valer (...)'. E foi apenas graças à ingerência de um nobre, que determinou a um seu criado que desse de comer aos padres que eles puderam dedicar-se às coisas da religião 22 .
\end{abstract}

\footnotetext{
17 Pérez-Mallaína, 1992: 248.

18 Ver, entre outros, Domingues, 1992: 56.

19 Inclusive sacerdotes portugueses, ver Ventura, 2000: 162 e ss.

20 Muñoz, 2004: 137-148; Fernández-Turégano, 2011: 161.

21 Nestola, 2016: 116.

22 Miceli, 1997: 161. Destaques meus.
} 
Em que pese seu papel de mediador da salvação das almas, o capelão era também um oficial, e isso decerto pesava na pouca consideração dos grumetes para com ele, sobretudo por ser um oficial que não tinha funções práticas nem conhecimentos marítimos úteis. $\mathrm{O}$ relato exemplifica uma das situações de conflito que, nas palavras de Rediker, forjou fraturas na cultura marítima: "a demonstração de força entre homem e homem, o conflito de classe nos assuntos de poder, autoridade, trabalho e disciplina" 23 , opondo oficiais e marinheiros comuns. Neste caso, grumetes espoliados não consideravam que um punhado de padres mareados merecia uma assistência especial: o enjoo denunciava a pouca experiência dos padres nas lidas marítimas, e a situação em que se encontravam não representava perigo para a embarcação. A ajuda prestada ao padre pelo serviçal de um nobre deixa claro o estabelecimento de alguma solidariedade entre nobres e religiosos, mas também deixa entrever que o nobre não estava apto a intervir diretamente no conflito, por exemplo exigindo dos grumetes que eles se comportassem como gente de categoria inferior quer eram. Passageiro, mesmo quando nobre, não devia interferir nas questões envolvendo a gente do mar.

Sabemos que o cargo de capelão dava aos seus ocupantes uma boa posição na escala hierárquica da vida marítima, mas nem sempre isso se evidenciava nos valores pagos por seu serviço. Responsável pelo atendimento dos homens em suas angústias espirituais, o capelão era um profissional cuja remuneração não se destacava no conjunto dos tripulantes, ao menos de acordo com um indício proveniente de uma viagem do galeão São Bartolomeu, que foi à Índia em 1589. O capelão receberia 2.000 réis ao mês, mesmo vencimento que o capitão, o condestável, o guardião, o sota-piloto, os carpinteiros e calafates. Melhor remunerados do que eles eram o piloto, o mestre e o contramestre (entre 2.400 e 3.000 réis). As piores remunerações eram as dos pajens (544 réis), grumetes e soldados (800 réis) e marinheiros (1.200 réis $)^{24}$. O fato do vencimento do capelão ser igual ao do capitão merece uma explicação: nessa altura, as principais funções do capitão não eram náuticas, para o que havia os pilotos. Seu papel se desempenhava em termos judiciais, militares e administrativos ${ }^{25}$. Amaral Lapa, ao mencionar quais eram os trabalhadores imprescindíveis a bordo na Carreira da Índia, não deixou de mencionar o capelão "e

23 Rediker, 1989: 154. O outro elemento definidor da cultura marítima, nas palavras do mesmo autor, seria a constante vigilância dos homens do mar para sobreviverem diante das forças das forças da natureza.

24 Domingues, 1998: 22.

25 Godinho, 2005: 51. 
outros inúmeros cargos, cujos ocupantes, perecendo durante a viagem (...), tinham a vaga preenchida na Bahia"26.

Os capelães marítimos desempenhavam funções semelhantes àquelas que cumpriam em terra, em instituições como irmandades e hospitais. Eram uma "espécie de intermediário entre a Terra e o Céu, entre Deus e os confrades"27, entendidos os confrades, no caso das embarcações marítimas, como uma congregação que não estava unida por adesão a uma instituição religiosa, mas sim pelas circunstâncias e, à moda das irmandades em terra, teriam direito à assistência dos capelães inclusive quando morriam a bordo e ganhavam sepultura no mar.

Do mesmo modo que ser capelão de irmandades era uma forma de garantir aos padres recém-ordenados um meio de subsistência enquanto não tinham um benefício colado ${ }^{28}$, exercer a função a bordo em caráter eventual podia atrair padres estabilizados em terra. Veremos isso com mais vagar quando analisarmos o tempo de experiência em navegação dos capelães e também quando analisarmos o engajamento de padres cuja intenção não era ficar por um tempo alongado a bordo, mas sim usar a viagem e a função de capelão como meio de viajar em razão de interesses pessoais ou de suas ordens (no caso dos regulares) e ainda receber remuneração e benefícios por isso.

Claro que no interior do mesmo recorte de tempo havia funções e hierarquias diferentes ligadas aos tipos de embarcações, às rotas ou legislações nacionais. Nas instruções sobre o funcionamento da Armada espanhola em 1735, por exemplo, o cirurgião (curador de corpos) e o capelão (curador de almas) subordinavam-se ao escrivão, reforçando tradições vindas da terra firme de se atribuir aos religiosos os cuidados de enfermaria, evidenciando também o minguado prestígio profissional dos cirurgiões embarcados nesse mesmo período ${ }^{29}$. Nas marinhas protestantes, mas não só, as práticas religiosas a bordo variaram muito. Rediker acredita que fosse mais provável a existência de serviço religioso formal nos navios maiores, mais comumente nos navios da Royal Navy devido à obrigação legal, e menos frequentemente nos navios mercantes, onde o serviço podia se fazer por insistência do capitão e ser conduzido por ele ou por um membro mais piedoso da tripulação ${ }^{30}$.

\footnotetext{
26 Lapa, 1968: 201.

27 Ferraz, 2014: 51.

28 Rodrigues, 2012: 83.

29 Nuñes e Villalba, 2012: 52.

30 Rediker, 1989: 171.
} 


\section{PERFIS DOS PROFISSIONAIS}

Partindo de dados de meados do século XVIII até as primeiras décadas do XIX, podemos traçar um perfil dos capelães embarcados nos navios lusos. A amostra que apresento reúne informações sobre 743 capelães, entre os quais a primeira distinção a ser apontada é o contingente majoritariamente secular desses homens face a uma reduzida minoria de membros de ordens religiosas. O clero secular era formado por "sacerdotes diocesanos, sem vínculos aos institutos regulares, também (...) designados por 'presbítero do hábito de São Pedro' para que fossem diferenciados dos membros das ordens regulares" 31 . Nesta amostragem, 685 capelães eram seculares, sendo 97 nomeados como "do hábito de São Pedro". Os restantes 58 eram membros de ordens assim distribuídos: 34 franciscanos, oito jesuítas ou ex-jesuítas, sete carmelitas, quatro capuchos ou capuchinhos, um beneditino, um barbadinho, um dominicano, um trinitário e um cuja letra do escrivão não pude decifrar.

Ausência de emprego e o parco aproveitamento dos clérigos foram comuns ao longo de todo o século XVIII, em um ambiente de abundância de clérigos, não obstante a ampliação das exigências aos candidatos às ordens sacras, que eram facilmente subvertidas. Patrocínios e investimento familiar favoreciam o ingresso na carreira eclesiástica mesmo para os mais pobres ${ }^{32}$, possibilitando alguma distinção social "até porque os montantes dos patrimônios exigidos não eram elevados e eram múltiplas e plásticas as formas de alcançar esse dote" 33 . Ao tempo do terremoto em Lisboa, em meados daquele século, o clero continuava a ser numeroso em Portugal, ao ponto de apenas cerca de um terço deles conseguir tornar-se cura ou vigário: "os restantes estavam reduzidos a pedinchar missas de intenção com a insistência e o descaramento de vendedores ambulantes que tentam colocar a sua mercadoria", muitos deles vivendo na pobreza ${ }^{34}$.

O número de membros de ordens religiosas em Portugal nos meados do século XVIII seria algo em torno de 10 e 15 mil, chegando a pouco menos de 17 mil no início do XIX. Esse número trazia implicações:

Uma das consequências visíveis do aumento da população eclesiástica foi o aparecimento de um 'clero desempregado', falando mesmo alguns autores na existência de 'uma verdadeira legião de clérigos vagabundos', que importaria quanti-

\footnotetext{
31 Rodrigues, 2012: 370.

32 Olival e Monteiro, 2003: 1216 e 1238.

33 Rodrigues e Olival, 2016: 36-37.

34 Chantal, 2005: 172-173.
} 
ficar com exatidão, identificando-se em simultâneo as raízes geográficas, familiares e sociais e os motivos que explicavam a sua mobilidade ${ }^{35}$.

Padres empobrecidos, neste caso, podem ter sido agentes da pressão sobre as autoridades do governo para garantir a obrigatoriedade legal de se levar capelães nos navios. Não é difícil imaginá-los à beira de um cais oferecendo seus serviços aos capitães, tentando conseguir um meio de subsistência diferente dos que ficavam em terra, pedinchando.

$\mathrm{O}$ caso dos ex-jesuítas merece um esclarecimento. Com a expulsão da Companhia de Jesus do Reino e das colônias, abriu-se a eles a opção de seguir para o exílio, a prisão ou, alternativamente, abandonar o antigo hábito. Dentre os que deixaram de fazer parte dos quadros jesuíticos, muitos se tornaram seculares, mas foram incluídos aqui na lista dos regulares. Navios não costumavam ser os lugares missionários dos membros dessa ordem: estes ex-jesuítas só apareceram aqui porque se adequaram, ao menos formalmente, aos trabalhos que lhes surgiram nesse contexto de adversidade.

A partir do quesito naturalidade, observa-se que a presença numérica mais significativa era de capelães vindos do norte do Reino.

Portugal era o lugar de nascimento da imensa maioria dos padres engajados, sendo os navios mercantes uma espécie de reserva de mercado para reinóis. Nada obscurece o fato de que, mesmo excluídos os homens que não sabemos onde nasceram, $84 \%$ dos capelães provinham do Reino, sendo $34 \%$ do norte (Entre Douro e Minho, Trás os Montes), 18\% do centro (Beira) e 23\% de Lisboa, seu entorno e áreas ao sul do Tejo (Alentejo e Algarves). As ilhas atlânticas entravam com $8 \%$ do contingente de padres embarcados e a presença do clero africano e de estrangeiros de outras áreas europeias era insignificante.

Não há levantamentos precisos sobre a naturalidade do clero nos domínios coloniais, o que levou historiadores a buscarem informações dessa natureza, por exemplo, nos dados dos clérigos que se habilitavam ao cargo de comissário do Santo Ofício ${ }^{36}$. A América portuguesa foi a única porção dos domínios coloniais cujo clero ali nascido teve alguma relevância no engajamento marítimo de capelães, mas é preciso lembrar que se tratava, em sua imensa maioria, de homens brancos e de ascendência lusa. Uma região como a Beira, por exemplo, enviava mais padres a bordo de navios mercantes do que todas as capitanias da América portuguesa juntas. Boxer afirmou que "quando eventualmente se desenvolveu um clero crioulo nas regiões mais povoadas, os seus membros preferiam normalmente ministrar aos amigos e parentes nas cidades

\footnotetext{
35 Rodrigues, 2010: 106.

36 Rodrigues e Olival, 2016: 29.
} 


\section{TABela I. LocAis DE NASCIMENTO DOS CAPELÃES}

\begin{tabular}{|l|r|}
\hline \multicolumn{1}{|c|}{ Região } & Quantidade \\
\hline Portugal (sem local) & 22 \\
\hline Entre Douro e Minho & 149 \\
\hline Trás os Montes & 10 \\
\hline Beira & 85 \\
\hline Lisboa e Estremadura & 83 \\
\hline Alentejo & 24 \\
\hline Algarves & 1 \\
\hline Açores & 32 \\
\hline Ilha da Madeira & 7 \\
\hline África & 5 \\
\hline América portuguesa/Brasil & 63 \\
\hline Espanha & 4 \\
\hline Itália & 2 \\
\hline Sem especificação & 256 \\
\hline Total & $\mathbf{7 4 3}$ \\
\hline
\end{tabular}

Fontes: Esta e as demais tabelas do texto baseiam-se nas seguintes fontes: Arquivos Nacionais/Torre do Tombo, Lisboa, Fundo Junta do Comércio (ANTT/JC): Livros 1 a 5; Maço 1, Caixas 1 e 2; Maço 1, Caixa 7; Maço 4, Caixa 13; Maço 34, Caixa 112 e 113; Maço 37, Caixa 128; Maço 62, Caixa 204; Fundo Feitos Findos (FF), Juízo da Índia e Mina, Maço 25, n. ${ }^{\circ}$ 4, Caixa 25; Arquivo Nacional, Rio de Janeiro, Fundo Junta do Comércio, Caixa 445, Pacote 2, fl. 10-12; Arquivo Histórico Ultramarino, Lisboa, Fundo Conselho Ultramarino (AHU/CU): Rio de Janeiro, Caixa 92, docs. 8023, 8032, 8033, 8037, 8038, 8044 e 8047; Caixa 93, docs. 8104 e 8105; Caixa 94, docs. 8151 e 8169; Caixa 95, docs. 8200, 8215, 8216, 8217, 8235 e 8236; Caixa 96, docs. 8300, 8319, 8320, 8340, 8341, 8362 e 8363; Caixa 97, docs. 8400, 8416, 8417, 8420, 8426, 8418. 8427, 8367, 8370 e 8375; Caixa 98, docs. 8439, 8441, 8452, 8483 e 8497; Caixa 99, docs. 8517, 8549 e 8554; Caixa 100, docs. 8649 e 8674; Caixa 129, doc. 10305; Caixa 133, docs. 10533 e 10591; Caixa 135, docs. 10731, 10735 e 10736; Caixa 140, doc. 10973; Caixa 144, docs. 11189, 11194 e 11195; Caixa 148, doc. 11368; Caixa 171, doc. 12696; Caixa 181, doc. 13210; Maranhão, Caixa 47, doc. 4644; Macau, Caixa 17, doc. 29. 
e vilas do que [se] fazer de missionários na selva, no sertão ou na savana" 37 , ao que poderíamos incluir, sem receio, os navios. Quanto ao clero nativo de outros domínios coloniais, encontrei pouquíssimos capelães africanos: João Inácio Binttan Cure (sic, provavelmente Bittencourt), natural da Ilha de Goré; Manuel Pereira Gomes, de São Tomé; Gaspar de Barros Reijo, de Luanda e, por fim, Manuel Coelho Rodrigues e Simião Antônio das Mercês, estes últimos nascidos na Ilha do Príncipe e os únicos cuja cor (preta) foi mencionada nos registros de matrícula ${ }^{38}$.

A quase ausência de capelães de outras nacionalidades europeias além da portuguesa (apenas quatro espanhóis e dois italianos) indica ao menos três possibilidades: a manutenção da reserva de mercado de trabalho marítimo para reinóis ${ }^{39}$; a tentativa de acesso controlado de religiosos (sobretudo os regulares) às rotas ultramarinas; a necessidade de ter a bordo um clero capaz de compreender a língua dos mareantes, majoritariamente lusófonos.

A idade e o tempo de engajamento dos capelães na marinha mercante também é explicitada nos registros de matrículas das tripulações. Os registros não informam a idade de 124 homens dos 743 que compõem a amostragem; assim, tomando como universo 619 capelães, distribui os dados na tabela a seguir.

37 Boxer, 1981: 86-87.

38 Matrículas da equipagens do navio N. S. de Nazaré e Santa Ana o Invencível e do Rainha dos Anjos, Arquivos Nacionais, Torre do Tombo, Lisboa, Fundo Junta do Comércio (ANTT/JC), Maço 34, Caixa 112. "Relação dos oficiais e mais pessoas da equipagem da corveta denominada São Pedro Gonçalves qualificado nesta Junta do Comércio deste Reino e seus domínios declarando fazer viagem para esse porto", ANTT/JC, Relações de equipagens de navios e passageiros, Maço 1, Caixa 5; "Lista da tripulação do navio N. S. da Lapa e Três Reis Magnos que segue viagem para a Bahia" e "Relação dos oficiais e mais equipagem da galera N. S. da Madre de Deus e São José que vai para Lisboa", ANTT/JC, Maço 34, Caixa 113.

39 Diferentemente do que parecia ocorrer nos navios da Espanha desde o século XVI, onde se verificava grande participação de estrangeiros nas tripulações, "podendo-se concluir que a participação dos forasteiros nas frotas e armadas das Índias alcançava percentuais elevadíssimos", ver Pérez-Mallaína, 1992: 248. 
TABela II. MÉdias etÁRIAS de CAPelães embarCAdos (1761-1822)

\begin{tabular}{|l|r|}
\hline De 20 a 25 anos & 25 \\
\hline De 26 a 30 anos & 166 \\
\hline De 31 a 35 anos & 120 \\
\hline De 36 a 40 anos & 110 \\
\hline De 41 a 45 anos & 64 \\
\hline De 46 a 50 anos & 52 \\
\hline De 51 a 55 anos & 25 \\
\hline De 56 a 60 anos & 19 \\
\hline De 61 a 65 anos & 5 \\
\hline De 66 a 70 anos & 8 \\
\hline Mais de 70 anos $(72$ a 76 anos $)$ & \\
\hline
\end{tabular}

Em outra oportunidade, pude reunir dados na mesma fonte acerca da idade de forros e escravos ${ }^{40}$, o que fornece parâmetros de comparação para uma análise focada em outro segmento profissional bem diverso. A tabela II refere-se a um tipo de profissional que, diferentemente de todos os outros, não adquiria sua formação no mar. Claro que os capelães aprendiam a lidar com as especificidades do trabalho nos navios, adequando as cerimônias religiosas e a aplicação dos sacramentos aos ritmos do trabalho e da natureza. Mas, para serem habilitados no ofício, padres necessariamente passavam antes por alguma formação em terra e o engajamento marítimo como capelães era uma opção posterior. Isso explica porque o início da vida profissional desses homens era comparativamente tardio, iniciando-se na faixa de 20 a 25 anos de idade, ao passo que outros profissionais começavam bem mais cedo. Escravos e libertos, os casos mais radicais e menos espontâneos de engajamento, começavam a trabalhar em funções marítimas entre os 5 e os 14 anos de idade.

O maior contingente dos capelães de navios situava-se na fase madura da vida, dos 26 aos 45 anos, e nisso não diferia da maior parte dos oficiais. De novo, a comparação com os escravos e libertos é reveladora: neste segmento, a maior parte dos engajados tinha idades entre 10 e 25 anos, certamente porque depois disso a força física exigida para o cumprimento das tarefas começava a

40 Rodrigues, 2015: 137. 
declinar, quando não eram apanhados pela morte ou vendidos a outros senhores a fim de desempenhar tarefas que exigiam menos de seus corpos já esgotados. Mas os capelães não exerciam trabalhos braçais, o que certamente possibilitava que suas carreiras a bordo fossem mais longas e permitia o engajamento de homens bem mais velhos que a maioria dos tripulantes. A tabela acima mostra que havia 57 capelães na ativa com mais de 60 anos de idade, representando quase $10 \%$ da amostra, número reduzido, mas não desprezível.

O tempo de experiência, conjugado à idade, é outro indicador de longevidade nos segmentos profissionais. No caso dos capelães, consegui reunir informações sobre a experiência contada em anos de 278 homens, sistematizadas na tabela a seguir.

TABela III. TeMPo DE EXPERIÊNCIA DOS CAPELÃEs (1767-1822)

\begin{tabular}{|l|r|}
\hline \multicolumn{1}{|c|}{ Tempo } & \multicolumn{1}{|c|}{ Registros } \\
\hline de 1 a 5 anos & 161 \\
\hline de 6 a 10 anos & 63 \\
\hline de 11 a 15 anos & 29 \\
\hline de 16 a 20 anos & 12 \\
\hline de 21 a 25 anos & 5 \\
\hline de 27 a 41 anos & 8 \\
\hline
\end{tabular}

Para outros 174 homens, a experiência foi contabilizada não em quantidade de anos de engajamento, mas sim em número de viagens: 125 deles eram de primeira viagem, 43 fizeram de uma a três viagens e seis capelães tinham de quatro a dezessete viagens no currículo.

Esses dados mostram que o tempo de engajamento marítimo dos capelães situava-se majoritariamente entre 1 e 10 anos, e há boas razões para isso. Entre elas, a possibilidade de tornar-se pároco em terra, desde que quisesse, fosse bem relacionado e demonstrasse experiência. $\mathrm{O}$ tempo que cumpriam como capelães de navios não representava a totalidade de suas carreiras, sendo encarado como uma fase da vida profissional que, na maioria dos casos, continuava em terra. Adiante, veremos que um bom número de padres tinha um engajamento marítimo ocasional, a fim de utilizar o meio de transporte para se deslocarem entre os domínios coloniais no cumprimento de funções religiosas, sobretudo quando se tratava de regulares ou quando tinham assuntos pessoais a resolver em lugares distantes daquele onde viviam a maior parte do tempo. 


\section{ENSAIOS DE PROSOPOGRAFIA}

Considerando os padres que tiverem um tempo mais alongado de engajamento e, portanto, deixaram rastros mais consistentes de suas carreiras na documentação, podemos ensaiar prosopografias de alguns capelães de navios.

Manuel Aires de Casal é um deles. O conhecido autor da Corografia brazílica ${ }^{41}$ informou, no subtítulo dessa obra, sua condição de religioso secular. Seus biógrafos não sabem ao certo as datas de seu nascimento (1754?) e morte (1821?). Sacramento Blake informa que ele nasceu em Pedrógão Grande, Distrito de Leiria, e que era formado em Teologia e Filosofia quando chegou ao Brasil, antes de 1796, onde foi capelão da Santa Casa de Misericórdia do Rio de Janeiro e sacerdote no Crato (Ceará) antes de voltar a Lisboa com a Corte retornada em $1821^{42}$. Estudiosos e comentadores desse autor colonial consideram sua vida misteriosa: Caio Prado Jr. o qualifica como um "simples colecionador e registrador de fatos", sem "vocação ou instinto científico algum"; ele foi "mais um excelente rebuscador de arquivos e bibliotecas do que um viajante atencioso às riquezas naturais do território brasileiro"43. O que podemos acrescentar à biografia de Casal diz respeito à sua chegada ao Brasil e à sua condição de viajante. Blake pareceu um pouco vago ao afirmar que Casal chegou ao Brasil antes de 1796, mas estava no caminho certo: Casal foi o capelão do $N$. S. da Antígua que, em 29 de julho de 1795, partiu de Lisboa em direção ao Rio de Janeiro. A matrícula do navio, como a de quase todos os que fizeram vela desde Lisboa naqueles anos, foi assinada pelo intendente da polícia Diogo Inácio de Pina Manique, e o capelão foi o provedor espiritual dos 41 homens a bordo. O navio deve ter chegado ao Brasil ainda em meados de 1795, onde Casal se fixou a partir de então, até voltar a Portugal pouco antes de morrer. Esse registro informa ainda que o padre em questão nascera em "Pedrogam", Priorado do Crato, no Alentejo, e era filho de José Aires e Luísa Barata. Ele não mencionou a própria idade nessa ocasião ${ }^{44}$.

$\mathrm{Na}$ verdade, o padre vivenciara outras viagens antes de se fixar no Brasil: ele servira como capelão do navio N. S. da Conceição Princesa de Portugal, que zarpou de Lisboa em 18 de janeiro de 1788 com 57 tripulantes, destinado

41 Casal, 1817. O livro "investe-se de grande importância para a história da leitura no Brasil, não apenas por ter sido o primeiro livro editado nesse país, como também por ter se constituído verdadeiro modelo corográfico para empreendimentos posteriores", ver Castro, 2016: 236.

42 Blake, 1883, vol. 6: 33.

43 Fernandes, 2013: 133 e 138.

44 "Relação da equipagem do navio $N . S$. da Antígua, que de presente segue viagem para o Rio de Janeiro este presente ano de 1795”, ANTT/JC, Maço 34, Caixa 113. 
a Macau e escalas nos portos asiáticos sob domínio luso. Nessa altura, Casal tinha 37 anos de idade, já era padre e somava 6 anos de experiência como tripulante. Se a idade de 37 anos alegada em 1788 estiver correta, Casal nasceu em 1751. Nos sete anos que separam as viagens ao Oriente e ao Brasil, não tenho certeza se ele permaneceu em Macau ou se manteve a atividade de capelão de navio. O certo é que ele voltara a Lisboa antes de 1795, ano em que embarcou para o Rio de Janeiro, novamente como capelão, e que sua experiência como viajante prosseguiu por alguns anos e ao menos uma viagem de ida e volta na mais longa e difícil carreira marítima da história lusa ${ }^{45}$. De todo modo, sua vida profissional assemelhou-se à de muitos outros padres que, sem paróquia definida ao concluírem sua formação, começou como capelão de navio para, mais tarde, se estabilizar de acordo com os contatos que conseguisse fazer, as mercês que viesse a receber e as aptidões intelectuais que desenvolvesse.

Padres prestavam socorro espiritual e vigiavam a ortodoxia católica a bordo, mas isso não os tornava imunes a certos desvios de comportamento e à delação. $\mathrm{O}$ fato de ser capelão de navio podia ser uma saída atrativa para religiosos denunciados, como o franciscano João de Santa Ana de Aguiar, embarcado em Lisboa com destino ao Rio de Janeiro em fins da década de 1770 no Invencivel ${ }^{46}$. Sabemos que ele passava longos períodos em terra, embora conhecesse bem os caminhos do mar: capelão do Santa Maria Maior, onde assistiu a 98 homens da tripulação, ele zarpou de Lisboa em fevereiro de 1782 com destino à Índia e escala no Rio de Janeiro ${ }^{47}$. Dois anos depois, tendo já regressado ao Rio de Janeiro, o padre fugiu dali para o Reino sem que saibamos o porquê. Ele foi capturado no Convento de São Francisco de Lisboa e reembarcado para a capital colonial ${ }^{48}$.

Ao ser denunciado em 1800, Santa Ana encontrava-se sob o abrigo dos carmelitas no convento destes no Rio, onde o comissário do Santo Ofício na cidade, frei Félix de Santa Teresa Nascentes, foi procurá-lo em 8 de abril. Nascentes recebera uma denúncia informando que, ao cumprir suas funções, o franciscano não respeitava a eucaristia e o jejum necessário à comunhão, pois "repetidas vezes tem dito missa depois de almoçar". No

\footnotetext{
45 ANTT/JC, Maço 34, Caixa 112, Matrículas de Equipagens.

46 "Processo do padre frei João de Santa Ana", 1801-1802, ANTT, Tribunal do Santo Oficio, Inquisição de Lisboa, proc. 4341.

47 ANTT/JC, Matrículas de Equipagens, Maço 34, Caixa 112.

48 Ofício de Pina Manique, intendente da Polícia de Lisboa, a Martinho de Melo e Castro, secretário da Marinha e Ultramar, 13 de outubro de 1784, Arquivo Histórico Ultramarino, Lisboa, Fundo Conselho Ultramarino, AHU/CU, Rio de Janeiro, Caixa 124, doc. 9989.
} 
Convento do Carmo, foi ouvido o mestre marceneiro Manuel Pereira Landim, nascido em Braga, casado e morador na Freguesia da Sé no Rio de Janeiro, que já denunciara Santa Ana ao vigário geral do bispado e tudo confirmou diante do comissário inquisitorial. Às 2 horas da madrugada de 13 de outubro de 1799, depois de ter "comido bastante biscoitinhos e bebido aguardente" e passando o resto da noite "brincando desonestamente como é seu costume", Santa Anna foi bater na porta do marceneiro, pedindo para que ele e sua família fossem ouvir a missa que o sacerdote rezaria na igreja do Bom Jesus do Calvário. Landim soube o que e o quanto o frei tinha comido em conversas com outros colegas de profissão e com parentes seus. A denúncia era agravada pela contumácia com que Santa Ana almoçava antes de oficiar missas e pela constância com que passava a noite "em brinquedos". O vigário geral mandara prender Santa Ana, mas ele refugiouse no Convento do Carmo e "me asseguram ter fugido para Angola", escreveu o comissário em 9 de abril, frustrado por não ter encontrado o denunciado ${ }^{49}$. Nada sugere que a postura pândega de Santa Ana fosse diferente quando vinha embarcado. No entanto, a denúncia contra ele não foi feita por tripulantes dos navios em que trabalhou, mas por gente de terra que, imersa na rede de familiares do Santo Ofício, não perdoou seus costumes desregrados que, a bordo, talvez não fossem tão ofensivos e perceptíveis à gente do mar, cujos horários de sono, refeições e reza eram peculiares se comparados às práticas de terra. Sua fuga para Angola, se de fato ocorreu, o lançou novamente nos circuitos atlânticos, dificultando a ação repressiva e reinserindo o denunciado em ambientes quem sabe mais tolerantes e que não lhe eram estranhos.

A maior parte dos padres matriculados como tripulantes de navios fizeram carreira nessa função, como vimos na tabela acima. Aquele sobre quem encontrei o maior número de ocorrências foi Bernardino de Sena. Nas matrículas dos tripulantes feitas no século XVIII, frequentemente constam descrições físicas dos embarcados, e as descrições dele feitas ao longo dos anos deixam saber que se tratava de um homem de estatura baixa, gordo (ou robusto, como preferiram alguns escreventes), com pelos brancos já mesclando seu cabelo e sua barba, sobrolhos pretos, olhos pardos, testa grande e feições miúdas em um rosto comprido e carnoso que, em 1770 apresentava "alguns sinais de bexigas". Sena foi acometido pela varíola entre 1767 (ano do primeiro registro, quando os sinais não foram mencionados em sua fisionomia) e 1770.

49 "Processo do padre frei João de Santa Ana", 1801-1802, ANTT, Tribunal do Santo Oficio, Inquisição de Lisboa, proc. 4341. 
Qualificado como "reverendo padre", "clérigo secular" e "presbítero do hábito de São Pedro", começou a navegar aos 26 anos de idade, já que o primeiro registro que encontrei sobre ele data de 14 de dezembro de 1767 , ocasião em que declarou ter 40 anos de idade e 14 de embarque, certamente sempre na função de capelão. $\mathrm{O}$ último registro data de 11 de janeiro de 1782 , o que indica que sua longa carreira no mar prosseguiu ao menos até os 55 anos de idade, totalizando quase 30 anos como padre mareante. Nesse longo percurso, Bernardino de Sena empregou-se em diversas embarcações: as corvetas São Paulo e N. S. da Oliveira (nesta última fez ao menos 2 viagens), o navio N. S. do Rosário, Santo Antônio e Almas (ao menos 4 viagens) e a galera N. S. da Conceição e Santa Rita. Nos percursos marítimos, ele conheceu três continentes. Primeiramente Lisboa, na Europa, onde nasceu na Freguesia de Santa Maria Madalena, filho de Manuel Peres de Carvalho e Helena da Cruz, e de onde partiram as embarcações que o levaram à África e à América. Sena especializou-se nas rotas das capitanias do norte da América portuguesa, provavelmente prestando serviços nos navios das companhias pombalinas do Grão-Pará e Maranhão e de Pernambuco e Paraíba. Na África, esteve em Cabo Verde, Bissau, Luanda e Benguela, decerto em navios negreiros que levaram carregações para a Bahia, o Maranhão e a Paraíba, esta última sua rota mais constante, já que ali esteve ao menos por quatro vezes ${ }^{50}$.

\section{ENGAJAMENTOS OCASIONAIS}

Referi acima os níveis de conflito envolvendo a presença dos capelães a bordo, a saber, o valor que se lhes devia pagar, as condições de trabalho e a dificuldade para encontrar sacerdotes dispostos a desempenhar suas funções no mar. Todavia, é importante que se diga que o engajamento desses profissionais nem sempre era de longa duração. Embora houvesse aqueles que viviam embarcados durante boa parte de suas atividades profissionais, outros se

50 ANTT/JC, Livro 4, Matrícula de equipagens de navios (1767-1769), N. S. do Rosário, Santo Antônio e Almas; Maço 1, Caixa 1, "Relação dos oficiais e mais pessoas da equipagem da galera N. S. do Rosário, Santa Ana, Santo Antônio e Almas que vai para Lisboa"; Maço 1, Caixa 2, "Relação dos oficiais e mais pessoas da equipagem da galera N. S. do Rosário, Santo Antônio e Almas que vai para Lisboa"; Maço 1, Caixa 2, "Relação dos oficiais e mais pessoas da equipagem da corveta por invocação São Paulo que se qualificaram pela Secretaria da Junta do Comércio que faz viagem para Cabo Verde e Bissau"; Maço 34, Caixa 112, Matrículas de Equipagens, N. S. da Oliveira e N. S. da Conceição e Santa Rita. Nenhuma das embarcações tripuladas por Bernardino de Sena aparece no http://www.slavevoyages.org/, acesso em junho de 2017. 
aproveitavam do ir e vir das embarcações entre os portos do Reino e dos domínios coloniais para cuidar de seus negócios — religiosos ou não- e engajaram-se eventualmente, por vezes para escapar de demandas na justiça. Os casos mencionados a seguir são reveladores dessas práticas.

Vejamos o que pretendiam aqueles que reivindicavam pagamentos nem sempre honrados pelos contratantes. Sabemos que, independentemente da hierarquia entre os cargos, a prática de acionar oficiais na justiça pela falta de pagamento era comum. Muitos tripulantes o fizeram, entre eles capelães como Inácio da Luz Botineli, que moveu três processos contra Ana Joaquina Soares, viúva do capitão Antônio Lopes Cardoso, com quem o padre havia navegado no Príncipe do Brasil, de propriedade da Companhia de Comércio de Pernambuco e Paraíba. A dívida somava pouco mais de 338 mil réis, mas Inácio desistiu das demandas em 1788, dois anos depois de iniciá-las ${ }^{51}$.

Os capitães, em geral responsabilizados juntamente com os donos dos navios, eram os mais acionados por tripulantes com soldadas em haver, como no caso do açoriano Luís Caetano de Fontes, capelão da galera $N$. S. da Conceição, Tentativa, que assistiu a 27 tripulantes na viagem de Lisboa a Belém do Pará em janeiro de $1792^{52}$. O lisboeta Pedro Henriques e Campos foi outro a buscar na justiça pagamento pelos serviços prestados a bordo do Bom Jesus d'Além, em viagem a Macau em 1794. Experimentado, este capelão navegava ao menos desde antes de 1786, quando o encontramos a bordo do São José Macapá, navio com 60 tripulantes na rota Lisboa-Recife ${ }^{53}$. O mesmo pode ser dito em relação a José Caetano Alves da Guerra, que pretendia o pagamento de sua soldada no N. S. do Monte do Carmo e Santa Teresa, Triunfo em $1791^{54}$.

Alguns capitães eram maus pagadores e contra eles vários tripulantes uniam-se em ações coletivas para receber suas remunerações. Os casos do São José Princesa Real, de 1772, e do Nossa Senhora da Graça, Grão Maranhão, de 1799 , são ilustrativos. No primeiro, o capelão uniu-se ao piloto, ao contramestre e à "mais gente da equipagem" para tentar obrigar o capitão a pagar uma quantia de mais de dois contos de réis. No segundo caso, o carmelita descalço José do Rosário, do Convento de Nossa Senhora do Desterro de

51 Conservatória da Companhia Geral de Pernambuco e Paraíba, ANTT, Feitos Findos (FF), Maço 17, n. ${ }^{\circ}$ 16, Caixa 22; Maço 36, n. ${ }^{\circ}$ 27, Caixa 47; e Maço 36, n. ${ }^{\circ}$ 30, Caixa 47.

52 ANTT/FF, Juízo da Índia e Mina, Maço 81, n. ${ }^{\circ}$ 4, Caixa 81, 1793. ANTT/JC, maço 34, Caixa 112.

53 ANTT/FF, Juízo da Índia e Mina, Maço 121, n. . 20, Caixa 121. ANTT/JC, Maço 34, Caixa 112.

54 ANTT/FF, Juízo da Índia e Mina, Maço 31, n. ${ }^{\circ}$ 11, Caixa 218. 
Olinda, recorreu ao prestígio de sua ordem para fazer o capitão (e dono) do navio saldar a dívida. $\mathrm{O}$ aporte da ordem como coautora da ação indica que parte do pagamento dos capelães de navios religiosos regulares era repassada às instituições que os abrigavam em terra ${ }^{55}$.

Por vezes, o pagamento tinha de ser renegociado, em virtude de alguma intercorrência não prevista no momento em que capitães e capelães se acertavam para a viagem. Parece ser o caso de João Pedro Borges de Góis que, em 1790, pretendia mais meia soldada pelo trabalho alongado no Santo Antônio Delfim que, ao navegar de Belém ao Reino, encalhou e precisou da ajuda de um navio inglês para transportar sua carga e seus tripulantes até o destino final ${ }^{56}$. As contínuas vezes em que as demandas envolvendo padres acabavam na justiça comum indicam que os sacerdotes não se limitavam a responder ou acionar outrem apenas no âmbito dos tribunais eclesiásticos ${ }^{57}$.

Fernando José Ribeiro de Freitas fora capelão no Minerva e São Macário, em viagem do Maranhão a Lisboa, e teria direito a uma soldada de 200.000, "por ser o que se costuma dar aos capelães por semelhantes viagens". Chegando a Lisboa, Pedro Nolasco Gaspar, o proprietário do navio, quis pagar apenas 25.000, pelo que Freitas o fez citar em uma ação sumária de soldadas em 22 de março de 1794. Gaspar afirmava que ao sair do porto de São Luís foi preciso pedir outro capelão ao governador do Maranhão, sem explicar a razão do pedido, se o capelão da viagem de ida tinha adoecido, falecido ou desistido de embarcar ${ }^{58}$.

Nem sempre as disputas se davam somente em torno do pagamento dos serviços que os próprios capelães faziam. Alguns deles podiam ser também senhores de escravos que levavam consigo, não apenas para servi-los, mas eventualmente às embarcações, tirando proveito e renda disso. Foi o que fez José Rodrigues Barreto, ao cobrar soldada do capitão do Grande Condestável de Portugal que, em viagem da Índia para o Reino iniciada em 1785, utilizara os serviços do escravo Daniel, pertencente ao capelão que, neste caso, tinha mais a oferecer do que socorro espiritual em seus mais de quinze anos de serviços em navios, o que talvez valorizasse suas soldadas. Na ação, o padre elencou diversos argumentos para a cobrança. Primeiramente, comprovou que Daniel, "rapaz preto", fora comprado em Bombaim e logo começou a trabalhar tanto para seu senhor como no serviço do navio, nas escalas feitas em

55 ANTT/FF, Juízo da Índia e Mina, Maço 9, n. ${ }^{\circ}$ 3, Caixa 399 e Maço 7, n. ${ }^{\circ}$ 22, Caixa 273 , respectivamente.

56 ANTT/FF, Juízo da Índia e Mina, Maço 29, n. ${ }^{\circ}$ 4, Caixa 216.

57 Muniz, 2015: 154.

58 ANTT/FF, Juízo da Índia e Mina, Maço 28, n. ${ }^{\circ}$ 10, Caixa 28. Não encontrei sentença. 
diferentes portos da Costa do Malabar. Mesmo que servisse apenas ao padre, tinha direito à soldada por conta do capitão, "pois este tinha obrigação de dar ao reverendo autor e ter pronto um criado para o servir, como ele não destinou outro algum". Não era a lei, mas sim o costume ou acertos prévios que ditavam a prática, na medida em que o capitão "pagou as soldadas aos escravos do calafate e tenente da tropa que serviam seus senhores. Este é o estilo marítimo, porque não aprontando criado para o navio aos escravos que servem seus senhores". Nas escalas de Damão e Goa, onde o capitão tinha moradia e hospedou o capelão e outros oficiais, Daniel ocupou-se do serviço da casa. De volta ao navio, o escravo foi matriculado como membro da equipagem e "era chamado ao quarto todas as noites, conforme o costume" ao longo dos seis meses que a viagem ainda durou até Lisboa. No cálculo da soldada devida, o capelão incluiu os biscoitos que o capitão não dera ao escravo, dez arrobas a cada 10 dias para cada servente. Por fim, José Rodrigues Barreto afirmava ser "pessoa legítima para pedir esta quantia [30.000], porque o escravo não tem próprio, e tudo adquire para seu senhor (...)"59.

Nem todos os problemas envolvendo os capelães eram judiciais, ainda que envolvessem o cumprimento de leis e costumes. Havia padres que, correspondendo à fama de indisciplinados que atingia toda a gente do mar, criavam problema e se metiam em confusões e brigas, não respeitando hierarquias nem a presença de passageiros ilustres a bordo. Aldair Rodrigues mencionou um fato desse tipo envolvendo um agostinho, Frei Brás, em viagem de Lisboa ao Rio de Janeiro em 1734. O religioso chamou de "judeu e cachorro" a Antônio Fernandes de Carvalho, familiar do Santo Ofício que vinha a bordo. Carvalho reagiu,

... dizendo que era familiar do Santo Ofício e o injuriante bem sabia disso. Tal reação não impediu o prosseguimento da ofensa, agora sob a afirmação: 'índio, índio, que bem podia ser índio sendo Familiar'. O ápice do insulto foi quando o Frei se referiu à medalha de Familiar do Santo Ofício que (...) Carvalho trazia ao peito como sendo 'penduricalho, que não valia nada ${ }^{60}$.

Brás bem sabia que não se podia ser judeu nem índio e, ao mesmo tempo, familiar da Inquisição. Não estamos diante de um homem que desconhecia as normas de pureza de sangue exigidas para a função; estamos, sim, diante de

59 ANTT/FF, Juízo da Índia e Mina, Maço 31, n. ${ }^{\circ}$ 7, Caixa 218. Encontramos o capelão Barreto navegando entre 1781 e 1796, particularmente no N. S. da Penha de França Aurora em repetidas viagens entre o Rio de Janeiro e Lisboa, ver ANTT/JC, Maço 4, Caixa 13; Maço 34, Caixas 112 e 113.

60 Rodrigues, 2007: 111. 
alguém que tinha a intenção de ofender seu oponente, graduando os impropérios do menos (judeu) ao mais injurioso (índio) no calor do conflito.

Em viagem à Índia, em 1773, Antônio de Noronha agradecia aos céus por ter feito embarcar um religioso consigo, "porque o capelão clérigo deste navio, além de ter pouca decência em outras, em dizer a missa em mangas de camisa e sobre ela a alva, muito remisso na sua obrigação, tem andado aos murros com oficiais sem conhecimento, tanto ele como os oficiais dos caracteres (...)"61. Padres, pelo visto, não se isentavam de brigas corporais quando se tratava de defender seus interesses: Joaquim José Pinto, capelão de galera, tinha um acordo com o capitão do N. S. do Rosário Paquete Feliz para levar escravos e outros bens em seu camarote, na viagem que fez a Benguela, mas um desentendimento entre os dois deixou registros de que o acordo não se cumpriu, tendo o capelão levado "muitos murros no rosto", além de ter ouvido "injúrias e palavras infames" de seu oponente ${ }^{62}$.

Frei Prudêncio dos Anjos, da Ordem Terceira de São Francisco, se não protagonizou episódios de violência, descumpriu a regra à qual se sujeitara: ele foi nomeado capelão do Rainha de Nantes, que partiria do Rio de Janeiro para a Colônia do Sacramento em 1768. A questão aqui se relacionava à Ordem, que determinara seu recolhimento ao convento: "porém, como já não havia tempo para se procurar outro capelão, por estar o dito navio em vésperas da partida", o Conde de Azambuja o mandou embarcar "com o mesmo emprego de capelão"63. A situação explicitava um conflito típico do regime do padroado: tendo que escolher entre as determinações de uma ordem religiosa e as leis que obrigavam a embarcar capelão em todos os navios mercantes, o vice-rei optou pela segunda alternativa, aparentemente, sem enfrentar a resistência do frei.

A possibilidade de usar os navios como meio de fuga criou diferentes situações. Sacerdotes que enfrentavam a justiça viram no engajamento em navios boas oportunidades de se livrarem de seus problemas. Os efeitos de uma ordem régia publicada em 2 de março de 1796 logo começaram a se fazer sentir: a ordem mandava voltarem a Lisboa na mesma embarcação todos os capelães dos navios da frota do Rio de Janeiro, com o objetivo declarado de impedir os que atravessassem o Atlântico de passarem para as Minas Gerais, ficando desobrigados apenas os que tivessem missões eclesiásticas no Brasil, o que não abrangia a região mineira. Não era o caso de Caetano Mendes: contrariando as ordens reais, Mendes tentou ir para Angola e acabou sendo

\footnotetext{
61 Noronha, 1995: 72.

62 Rodrigues, 2013: 152.

63 Oficio dirigido a Francisco Xavier de Mendonça Furtado, 14 de agosto de 1768, AHU/ CU, Rio de Janeiro, Caixa 93, doc. 7568.
} 
preso por ordem do bispo do Rio de Janeiro. A prisão fora arranjada pelo próprio padre, que não queria regressar ao Reino, ou ao menos assim pensava o vice-rei, ao pedir ao bispo para manter Mendes na cadeia. O bispo, todavia, mandou soltá-lo após ouvir de três grumetes que Mendes era mesmo padre e que "veio dizendo missas na viagem, e confessando os moribundos". Não sabemos se os grumetes enganaram as autoridades ou foram enganados pelo padre, sobre quem pesava a desconfiança de falsidade ${ }^{64}$. Os capitães de 25 navios da frota foram chamados para averiguar se os capelães que tinham vindo estavam matriculados para fazer o caminho de volta a Lisboa, tendo Mendes vindo de Lisboa como capelão do N. S. de Nazaré e Santo Antônio ${ }^{65}$. Caetano Mendes, nome falso do homem que, na verdade, chamava-se Cristóvão Alves Brandão, não conseguiu provar que tomara as ordens e nem explicar o motivo que o tinha levado a mudar de nome e não querer regressar a Portugal. O Conde da Cunha o mandou de volta a Lisboa a bordo do Bom Jesus d'Além e N. S. da Esperança, juntamente com outro suposto padre, Francisco da Trindade, nascido no Rio de Janeiro, mercedário que tomara o hábito em Buenos Aires e era conventual no Maranhão em 1766, informações que no Brasil não se podiam confirmar ${ }^{66}$.

Em outro caso de prisão, relativo ao padre Atanásio Gomes em 1767, na Ilha das Cobras, o autor da ordem fora o vice-rei Conde de Azambuja. A razão era Gomes ter vindo do Reino portando um passaporte no qual não se informava sua antiga condição de jesuíta ${ }^{67}$. Mais de dez anos depois, a tensão decorrente da expulsão dos membros da Companhia de Jesus ainda era sensível. O padre foi matriculado em Lisboa como "sacerdote do hábito de São Pedro" e, na viagem de volta, informa-se que ele fora jesuíta "e por estar recolhido em uma fortaleza não se lhe tomaram as feições". Diferentemente do que ocorria com a maioria das matrículas de capelães, sobre Gomes nada foi inscrito: idade, naturalidade, tempo de experiência ou nomes dos pais ${ }^{68}$, o

${ }^{64}$ Oficio do vice-rei Conde da Cunha a Francisco Xavier de Mendonça Furtado, secretário da Marinha e Ultramar, 11 de novembro de 1765. AHU/CU, Rio de Janeiro, Caixa 76, doc. 6896.

65 "Auto de diligência que mandou fazer o desembargador Gonçalo José de Brito Barros", iniciada em 2 de julho de 1795. AHU/CU, Rio de Janeiro, Caixa 76, doc. 6896,

66 Oficio do vice-rei Conde da Cunha a Francisco Xavier de Mendonça Furtado, secretário da Marinha e Ultramar, 16 de abril de 1766. AHU/CU, Rio de Janeiro, Caixa 78, doc. 7018.

67 Ofício dirigido a Francisco Xavier de Mendonça Furtado, 24 de novembro de 1767, AHU/CU, Rio de Janeiro, Caixa 83, doc. 7408.

68 O navio zarpara do Rio de Janeiro em torna-viagem para Lisboa em 24 de novembro de 1767, ver ANTT/JC, Maço 1, Caixa 1, "Relação das pessoas de que se compõem a equipagem do navio N. S. do Carmo e Senhor da Cana Verde...". 
que certamente se devia à sua tentativa de vir ao Brasil sem que se soubesse de seu passado jesuítico.

Em outras situações, a figura dos capelães se confundia com a de comerciantes. Um padre de nome Ricardo, por exemplo, contratava os serviços de tripulantes como o despenseiro Davi Cardoso, a quem deveria pagar 4.480 pelo frete de 32 meios de refugos de solas de couro, vindos da Bahia para o Reino em 1775 a bordo do Santíssimo Sacramento e N. S. do Pilar. O padre talvez tivesse compradores para sua encomenda, mas sem o pagamento devido, Cardoso recusava-se a entregar a mercadoria ${ }^{69}$.

Outros homens, como Manuel Francisco da Costa, José Guedes Dias e João José Vieira, podem nos guiar na temática dos padres-negociantes, pois todos eles atuaram como intermediários de transações mercantis. Costa, morto na escala baiana de uma viagem entre Lisboa e o Rio de Janeiro, deixou aos herdeiros o ônus de prestar contas a um certo Pedro Antônio de Miranda, que entregara ao padre "um negócio de fita lustrina" a ser vendida nos portos por onde ele passaria ${ }^{70}$. Dias trazia uma carga de fazendas de um negociante do Porto para ser negociada no Recife em 1809, ocasião em que morreu o capitão do navio, provavelmente sócio do padre na transação ${ }^{71}$. Por fim, o capelão Vieira, juntamente com o capitão do navio, respondia pela dívida de uma letra de risco sobre o navio Santo Antônio Delfim, em viagem a Pernambuco ${ }^{72}$.

Em novembro de 1805, o padre Joaquim Inácio Moreira, presbítero secular, morador na vila de Santos, denunciou o padre José Pais de Brito ao comissário José Xavier de Toledo. Brito era capelão do Princesa da Beira. Meses antes, estando esse navio no porto de Santos, Brito teria quebrado o sigilo sacramental ao contar a Moreira que o contramestre, em confissão, afirmou ter matado uns porcos "selváticos" e que, como capelão, ele mandara restituir os animais ao dono. Moreira avaliou que a situação era da alçada do Santo Ofício que, todavia, não levou a denúncia adiante ${ }^{73}$. A situação pareceu irrelevante para a Inquisição, mas não para o historiador. Pela denúncia, fica claro que Brito quis gabar-se de sua proeminência sobre os homens embarcados, mas talvez tenha aprendido a escolher melhor seus interlocutores, bem como a ter mais cuidado

69 ANTT/FF, Juízo da Índia e Mina, Maço 12, n. ${ }^{\circ}$ 1, Caixa 320.

70 Ação cível de libelo, 1799, ANTT/FF, Juízo da Índia e Mina, Maço 124, n. ${ }^{\circ}$ 2, Caixa 124.

71 Autos de habilitação de Antônio José da Silva Braga, 1809, ANTT/FF, Juízo da Índia e Mina, Justificações Ultramarinas, Brasil, Maço 76, n. ${ }^{\circ} 5$.

72 Ação cível de assinação de dez dias, em que é autor Bernardo José Lopes, 1787, ANTT/ FF, Juízo da Índia e Mina, Maço 3, n. ${ }^{\circ}$ 23, Caixa 269.

73 "Denúncia contra o padre José Pais de Brito", 1805, ANTT, Tribunal do Santo Ofício, Inquisição de Lisboa, Processo 13966. 
ao manejar identidades e solidariedades cambiantes em seu cotidiano. Ao fiscalizar a propriedade alheia e mencionar segredos de confissão a um colega de ofício em terra, ele correu riscos, como a denúncia comprova.

Atitudes como essas podem ser creditadas à ambiguidade no exercício profissional de muitos desses homens. Como vimos acima, as matrículas de tripulantes revelam a idade e o tempo de engajamento nos ofícios marítimos, mas muitos capelães, diferentemente de outros profissionais, atuavam em navios de forma ocasional e nem sempre comprometida com o comportamento que se esperava de um tripulante que convivia anos a fio com gente do mar, por vezes na mesma embarcação.

Muitos padres tornavam-se capelães de navio com o objetivo de viajar, ganhar algum dinheiro no deslocamento e chegar a um destino longínquo a fim de resolver problemas pessoais ou das suas ordens religiosas, quando se tratava de membros do clero regular. Os exemplos são inúmeros.

Questões familiares moviam, por exemplo, o beneditino Joaquim Xavier da Conceição e Melo, pregador da Capela Real, a pedir pedia licença em 1808 para vir como capelão do Protetor General a fim de tratar de pendências nos "Estados da América e cidade do Rio de Janeiro e suas vizinhanças", onde viviam seus tios e irmãos. O superior da ordem lhe concedeu o tempo necessário para "concluir os seus negócios"74. "Negócios que tem a tratar" no Rio de Janeiro também mobilizaram o padre Antônio Ribeiro Ferrão a pedir passaporte para vir como capelão do Princesa do Brasil ou do Oceano, já que o capitão de outra embarcação, o Despique, não o quisera levar por ter recomendação de embarcar outro capelão ${ }^{75}$.

A transferência da Corte para o Rio de Janeiro valeu de argumento e serviu de oportunidade para muitos, como o dominicano Antônio Joaquim Correia, que pleiteou apoio à sua pretensão de ser nomeado capelão de um dos navios que transportava as tropas para a nova sede da monarquia em 1808. Correia continuou navegando, pois o reencontramos pedindo passaporte para voltar de Lisboa ao Rio em 1814 como capelão no São José Fênix ${ }^{76}$. Fernando de Maria Santíssima, companheiro de ordem de Correia, estava no Porto em 1811 e pretendia vir ao Rio de Janeiro como capelão ou simples passageiro em um brigue, o que indica um motivo de ordem pessoal em sua viagem ${ }^{77}$.

\footnotetext{
74 AHU/CU, Rio de Janeiro, Caixa 252, doc. 17169.

75 AHU/CU, Rio de Janeiro, Caixa 253, doc. 17277, c. 1809.

76 AHU/CU, Rio de Janeiro, Caixa 253, doc. 17255, de 1808; Caixa 269, doc. 18162, c. maio 1814.

77 AHU/CU, Rio de Janeiro, Caixa 263, doc. 18056. O frei voltaria à cidade em 1814, como capelão no Aurora, cf. AHU/CU, Rio de Janeiro, Caixa 269, doc. 18627.
} 
"Negócios próprios e de sua família" também moviam o franciscano frei Joaquim de Santa Clara a vir ao Rio por capelão no União em 1815. Mas ele acabou adoecendo e o mestre do navio pediu autorização para que um dos dois missionários que vinham no mesmo navio como passageiros o substituíssem nos "ministérios que exigem a nossa Santa Religião"78. A movimentação de padres como capelães eventuais foram sucessivas, sobretudo em viagens ao Rio de Janeiro no período do Reino Unido. A quase totalidade dos pedidos foi formulada por membros de ordens religiosas, dado que indica não apenas uma movimentação de homens por diferentes espaços conventuais, mas também a vigilância mais constante sobre os regulares, fruto de uma ambiguidade na obediência ao rei e aos superiores eclesiásticos. As restrições vinham dos séculos anteriores, incluindo a proibição de instalação das ordens religiosas em lugares como Minas Gerais ${ }^{79}$, mas a implantação da Corte portuguesa no além-mar foi um fator de reforço na vigilância, sobretudo pela condição de guerra no mar e em terra a partir da invasão franco-espanhola.

Os padres com funções militares também tinham sua movimentação controlada. Foi o caso de Miguel de Moraes Antas, capelão de um regimento de infantaria no Rio de Janeiro, que se fez embarcar como capelão na galera Europa. A orientação do Conde de Linhares era que, caso o navio fosse vendido na porção europeia do Reino, as autoridades locais deveriam facilitar o retorno de Antas à Corte do Rio de Janeiro, para reintegrá-lo o quanto antes ao seu regimento ${ }^{80}$. Aparentemente, Antas não seguiu nessa viagem, sendo designado em seu lugar o padre Joaquim José Flores, que tentou de tudo para evitar o embarque e acabou preso por isso. O capitão da galera queixou-se de que Flores pedia uma soldada exorbitante, entre outras "despropositadas condições que exige (...) fora do costume e praxe do comércio em tais casos". Uma declaração de vários capitães ancorados no Rio de Janeiro afirmava que a soldada de capelão, dependendo do ajuste e do número de missas rezadas a bordo, variava de 30.000 a 120.000 . Flores se defendeu, escrevendo ao vigário geral que jamais se eximira de servir à Igreja e ao Estado mas, naquele momento, vivia em estado de completa indigência e "privado de todos os meios para uma tão longa viagem". Por menos de 200.000 réis o padre não queria ir, considerando o risco pelo estado de guerra em que Portugal se achava, "cujas circunstâncias não militam comigo que sou deste país [Brasil] e não me convém viajar". Flores acabou indo a Lisboa obrigado, mas recebeu

78 AHU/CU, Rio de Janeiro, Caixa 272, docs. 18809 e 18820, c. junho de 1815.

79 Sobre as restrições aos padres regulares em Minas Gerais, ver Scarano, 1978: 16-17. Souza, 1986: 174.

80 AHU/CU, Rio de Janeiro, Caixa 255, doc. 17411, 29 de agosto de 1809. 
uma soldada de 150.000. Em 1810, os donos do Europa não o quiseram recontratar, alegando que tinham que consertar o navio e não conheciam o destino da próxima viagem, sugerindo que, se quisesse mesmo voltar ao Rio de Janeiro, Flores deveria pagar as despesas de seu próprio bolso e vir como passageiro ${ }^{81}$.

Indigência também era a condição alegada pelo padre Manoel de Macedo e Silva Bacelar para se recusar a seguir viagem em um navio. O mestre Joaquim José Pereira Alegria contratara Bacelar como capelão do N. S. do Amparo, Paquete d'Ásia em 18 de setembro de 1787, mas este se recusou a ir diante do longo atraso na partida, já que até fins de janeiro de 1788 o navio ainda estava ancorado em Lisboa. Bacelar, "presbítero secular do hábito de São Pedro", alegava que "lhe tem ocorrido vários incidentes por onde se lhe fez impossível o embarque, e por esta razão requereu à Intendência para conseguir por-se-lhe verba de desobriga no Livro de Matrícula, e com efeito alcançou". No requerimento de desobriga, Bacelar diz que o capitão do navio lhe dera "quatro ou cinco moedas para seu preparo", mas como o navio não saiu no tempo determinado e o padre "se acha em grave necessidade, motivada pela demora que tem tido", pedia para não ter de devolver o adiantamento $^{82}$.

Gregório da Conceição, agostinho descalço, somou-se à lista dos padres com interesses pendentes nos dois lados do Atlântico e que se empregava como capelão para resolver seus problemas. Em 1809, estando no Reino, ele conseguiu licença de seus superiores para ir ao Rio de Janeiro tratar de negócios da casa de sua mãe, viúva, sob a alegação de ser filho único. Anos depois, de volta a Portugal, renovou seu pedido de regresso à Corte na América, desta feita sem alegar nenhuma questão pessoal e vindo como capelão do Robusto em $1813^{83}$.

\section{CONSIDERAÇÕES FINAIS}

Uma história social do clero vem ganhando algum terreno nas historiografias de Portugal e do Brasil. De acordo com Aldair Rodrigues, havia no Reino de Portugal uma "estabilidade paroquial", sendo a maioria dos sacerdotes recrutados nos próprios locais de nascimento ou em regiões próximas, e que

\footnotetext{
81 AHU/CU, Rio de Janeiro, Caixa 255, doc. 17444, c. outubro de 1809.

82 ANTT, Maço 34, Caixa 112, Junta do Comércio, Matrículas de Equipagens.

83 AHU/CU, Rio de Janeiro, Caixa 254, doc. 17375, 21 de junho de 1809; Caixa 268, doc. $18527, c$. outubro de 1813.
} 
permaneciam na mesma paróquia para as quais eram designados. Para o Brasil, tal afirmação ainda carece de base empírica, mas tanto de um lado do Atlântico como do outro também havia mobilidade, dada pela ascensão a níveis superiores da hierarquia eclesiástica, em busca de melhor renda pessoal e promoção profissional:

A carreira eclesiástica oferecia, à partida, diversas oportunidades profissionais, nem sempre relacionadas com as funções religiosas, mas, na prática, verificava-se que, em termos das trajetórias sociais potenciais, existiam diferenças evidentes, sendo possível detectarmos uma relação entre a origem social do indivíduo e o grau e a função que desempenhava ou a que podia aspirar ${ }^{84}$.

No século XVIII, expandiram-se as zonas de colonização na América portuguesa, a partir da exploração de metais preciosos em regiões como Minas Gerais, Goiás e Mato Grosso, "mais permeáveis à mobilidade social e à formação rápida de grupos intermédios por meio das carreiras eclesiásticas (entre outras hipóteses)" 85 . Não por acaso, a proibição da fixação de ordens nesses lugares e o controle da circulação marítima tornaram-se mais rigorosos no mesmo período.

Dispor de sacerdotes nas embarcações mercantes, engajados por anos a fio, nem sempre era fácil, mas a Coroa não desistiu da obrigatoriedade de mantê-los a bordo senão a partir das primeiras décadas do século XIX. A mobilidade, como se viu neste texto, para além da perspectiva da Coroa e do padroado, era uma expectativa dos clérigos e incluía o trânsito espacial dos capelães. Isso não desmente o anseio de aumento de renda e promoção ou simplesmente uma opção para exercer a atividade eclesiástica. Tornar-se capelão de bordo permitia desde um tempo longo de engajamento marítimo até tempos curtos de exercício sacerdotal que possibilitassem a viagem para resolução de problemas pessoais ou das ordens (quando era o caso) ou uma renda capaz de garantir a subsistência enquanto não havia uma paróquia para se ocupar definitivamente, algo que talvez nem todos os padres desejassem.

$\mathrm{Na}$ marinha mercante, as formas de recrutamento e de negociação de soldadas dos capelães diferiam daquelas dos demais membros da tripulação. Se os capitães eram, por vezes, donos ou sócios dos navios, e os demais oficiais e marinheiros comuns eram contratados como aprendizes ou lançavam mão de suas habilidades e experiência para conseguir trabalho, com os capelães não era assim. A presença deles a bordo decorria de exigências legais, típicas do padroado, e em certa medida tinha um caráter missionário: é conhecida a

\footnotetext{
84 Rodrigues, 2010: 107.

85 Rodrigues e Olival, 2016: 61
} 
fama de irreligiosos que pairava sobre os homens do mar, imperfeitamente cristianizados. Cuidadores de almas, os capelães também cumpriam seus deveres no batismo de africanos traficados pelo Atlântico. Esses são aspectos tratados na historiografia das religiões e que não foram negligenciados aqui, embora a ênfase tenha recaído em questões profissionais relevantes: negociação de pagamentos, circulação das gentes de quem as monarquias desconfiavam, interesses pessoais como motivadores do engajamento e diferenciação nos movimentos de padres regulares e seculares.

Os capelães embarcados na marinha mercante se apresentam, assim, em aspectos e situações multifacetados, todos eles relevantes para a compreensão do papel histórico que desempenharam e que ainda suscitam estudos mais aprofundados.

\section{BIBLIOGRAFIA}

Blake, Augusto Vitorino Alves Sacramento, Dicionário bibliográfico brasileiro, Rio de Janeiro, Imprensa Nacional, 1883, vol. 6.

Bluteau, Raphael, Vocabulario portuguez \& latino, Coimbra, Collegio das Artes da Companhia de Jesu, 1712, vol. 2.

Boxer, Charles R., A igreja e a expansão ibérica (1440-1770), Lisboa, Edições 70, 1981.

Boxer, Charles R., O império marítimo português (1415-1825), São Paulo, Cia. das Letras, 2002.

Casal, Manuel Aires de, Corografia brazilica, ou relação historiográfica do Reino do Brasil composta e dedicada a Sua Majestade Fidelíssima por um presbitero secular do Grão Priorado do Crato, Rio de Janeiro, Imprensa Régia, 1817, 2 tomos.

Castro, Pérola Maria Goldfeder Borges de, "Inventários de um mosaico: Representação espacial e olhar corográfico no Brasil, século XIX”, Faces da História, III/2 (Assis, jul.-dez. 2016): 213-229.

Chantal, Susanne, A vida quotidiana em Portugal ao tempo do terramoto, Lisboa, Livros do Brasil, 2005.

Domingues, Francisco Contente, "Navios e marinheiros", Miguel Chandeigne (ed.), Lisboa ultramarina (1415-1580): a invenção do mundo pelos navegadores portugueses, Rio de Janeiro, Jorge Zahar, 1992.

Domingues, Francisco Contente, A Carreira da Índia, Lisboa, s/e, 1998.

Fernandes, Antônio Carlos Sequeira. et al, "Aires de Casal, o beemonte de Jó e o registro das ocorrências fossilíferas brasileiras no início do século XIX", Filosofia e História da Biologia, VIII/2 (São Paulo, 2013): 133-150. 
Fernández-Turégano, Carlos Pérez, "El cuerpo de capellanes de marina en el siglo XVIII: ordenación legal y consolidación”, Leandro Martínez Peñas e Manuela Fernández Rodríguez, El Ejército y la Armada en el Noroeste de América: Nootka y su tiempo, Madrid, Universidad Rey Juan Carlos, 2011: 161-210.

Ferraz, Norberto T. Gonçalves, A morte e a salvação da alma na Braga setecentista, Braga, Instituto de Ciências Sociais da Universidade do Minho, 2014. Tese dout. História.

Godinho, Rui Landeiro, A Carreira da Índia: aspectos e problemas da torna-viagem (1550-1649), Lisboa, Fundação Oriente, 2005.

Lapa, José Roberto do Amaral, A Bahia e a Carreira da Índia, São Paulo, Cia. Ed. Nacional/Edusp, 1968.

Lara, Silvia Hunold, Legislação sobre escravos africanos na América portuguesa, Madrid, Mapfré, 2000.

Lara, Silvia Hunold, Fragmentos setecentistas: escravidão, cultura e poder na América portuguesa, São Paulo, Cia. das Letras, 2007.

Miceli, Paulo Celso, O ponto onde estamos: viagens e viajantes na história da expansão e da conquista (Portugal, séculos XV e XVI), Campinas, Ed. da Unicamp, $1997,2^{\mathrm{a}}$ ed.

Muniz, Pollyanna Gouveia Mendonça, "Religião e política: o clero nos tempos de Pombal (Maranhão, século XVIII)”, Almanack, 9 (Guarulhos, 2015): 153-165.

Muñoz, Margarita Gil, La vida religiosa de los mareantes: devociones y prácticas, Madrid, Ministerio de Defensa/Instituto de Historia y Cultura Naval, 2004.

Nestola, Paola, "Dominará de mar a mar, desde o rio até às extremidades da terra': tópicos da comunicação do poder religioso nos testemunhos escritos e visuais luso-brasileiros (séc. XVI-XVIII)", Revista de História da Sociedade e da Cultura, 16 (Coimbra, 2016): 111-136.

Noronha, António José de, "Diário dos sucessos da viagem que fez do Reino de Portugal para [a] cidade [de] Goa, Dom (...), Bispo de Halicarnasso, principiada aos 21 de abril de 1773", Carmen M. Radulet (ed.), Obras completas de D. António José de Noronha, Lisboa, Fundação Oriente, 1995, vol. 2.

Nuñes, Marcelo Frías e Villalba, Peça Hernandéz, "La sanidad y los espacios marítimos: entre la Ilustración y la España liberal”, Manuel-Reyes García Hurtado (ed.), La Armada española en el siglo XVIII: ciencia, hombres y barcos, Madrid, Síliex, 2012.

Olival, Fernanda e Monteiro, Nuno Gonçalo, "Mobilidade social nas carreiras eclesiásticas em Portugal (1500-1820)”, Análise Social, 37/165 (Lisboa, 2003): 1213-1239.

Pérez-Mallaína, Pablo E., Los hombres del océano: vida cotidiana de los tripulantes de las flotas de Indias, siglo XVI, Sevilha, Servicio de Publicaciones de la Diputación de Sevilla, 1992. 
Rediker, Marcus, Between the Devil and the Deep Blue Sea: Merchant Seamen, Pirates, and the Anglo-American Maritime World (1700-1750), Nova York, Cambridge University Press, 1989.

Rodrigues, Aldair Carlos, Sociedade e Inquisição em Minas colonial: os familiares do Santo Ofício (1711-1808), São Paulo, FFLCH/USP, 2007. Dissert. mest. em História.

Rodrigues, Aldair Carlos, Poder eclesiástico e Inquisição no século XVIII luso-brasileiro: agentes, carreiras e mecanismos de promoção social, São Paulo, FFLCH/ USP, 2012. Tese dout. História.

Rodrigues, Aldair Carlos e Olival, Fernanda, "Reinóis versus naturais nas disputas pelos lugares eclesiásticos do Atlântico português: aspectos sociais e políticos (século XVIII)", Revista de História, 175 (São Paulo, jul.-dez. 2016): 25-67.

Rodrigues, Jaime, De costa a costa: escravos, marinheiros e intermediários do tráfico negreiro de Angola ao Rio de Janeiro (1780-1860), São Paulo, Cia. das Letras, 2005.

Rodrigues, Jaime, "Escravos, senhores e vida marítima no Atlântico: Portugal, África e América portuguesa, c.1760-c.1825", Almanack, 5 (Guarulhos, jan.-jun. 2013): 145-177.

Rodrigues, Jaime. "Circulação atlântica: idade, tempo de trabalho e funções de escravos e libertos na marinha mercante luso-brasileira, séculos XVIII e XIX", História, XXIV/2 (Franca, jul.-dez. 2015): 128-145.

Rodrigues, José Damião, "Família e clero em Portugal”, Juan Hernández Franco e Mafalda Soares da Cunha (ed.), Sociedade, Família e Poder na Península Ibérica. Elementos para uma História Comparativa / Sociedad, Familia y Poder en la Península Ibérica. Elementos para una Historia Comparada, Lisboa, Edições Colibri/CIDEHUS, Universidade de Évora/Universidad de Murcia, 2010, 103-127.

Scarano, Julita, Devoção e escravidão: a Irmandade de Nossa Senhora do Rosário dos Pretos no Distrito Diamantino no século XVIII, São Paulo, Cia. Ed. Nacional, 1978. $2^{\mathrm{a}}$ ed.

Souza, Laura de Mello e, Desclassificados do ouro: a pobreza mineira no século XVIII, Rio de Janeiro, Graal, 1986. $2^{\mathrm{a}}$ ed.

Ventura, Maria da Graça A. Mateus, Portugueses no descobrimento e conquista da Hispano-América: viagens e expedições (1492-1557), Lisboa, Colibri, 2000.

Verger, Pierre, Notícias da Bahia de 1850, São Paulo, Corrupio, Fundação Cultural do Estado da Bahia, 1981.

Fecha de recepción: 20 de julio de 2017.

Fecha de aceptación: 5 de septiembre de 2017. 


\section{Capellanes en la marina mercante portuguesa: roles y perfiles profesionales (siglos XVIII y XIX)}

Entre las diferentes profesiones encontradas en las fuentes que se refieren a la marina mercante portuguesa en los tiempos modernos, los capellanes destacan como profesionales cuya formación fue forjada exclusivamente en tierra. Los capellanes fueron responsables de la ayuda espiritual de la tripulación. El objetivo de este artículo es definir tanto las funciones como los roles de estos hombres. Seguidamente, se propone perfilar breves biografias profesionales de algunos capellanes que viajaron desde el puerto de Lisboa a los dominios de Ultramar, especialmente de aquellos que lo hicieron a la América portuguesa entre mediados del siglo XVIII y las primeras décadas del XIX. Se trata así de enfatizar la antigüedad de la presencia de los sacerdotes católicos a bordo de los navios portugueses.

PALABRAS ClaVE: historia maritima; navegación; perfiles profesionales; capellán maritimo.

\section{Chaplains in the Portuguese merchant navy: professional profiles and roles (eighteenth and nineteenth centuries)}

Of the different professions found in sources referring to the Portuguese merchant navy in modern times, chaplains stand out as professionals who received their training exclusively on dry land. They were responsible for the spiritual assistance of the crew. This article seeks to define their functions and roles. It goes on to outline brief professional biographies of some of the chaplains who travelled from the port of Lisbon to overseas territories, particularly those who did so to Portuguese America between the mid-eighteenth and early decades of the nineteenth century. The aim is to emphasize the long-standing tradition of Catholic priests on board Portuguese ships.

KEY WORDS: marine history; navigation; professional profiles; naval chaplain. 